\title{
Hirwan Kuardhani ${ }^{1}$
}

Jurusan Teater, Institut Seni Indonesia Yogyakarta

\begin{abstract}
Potehi (布袋戏) puppet theater in Java is called as Chinese puppet and originated from Fujian (福建) and Guangdong (广东) Province. Chinese puppets that were allegedly meant here is Potehi because the forms of other kinds of puppet theater from China was not discovered the traces. Leather puppet, such as Purwa, or string puppet (marionette), or even Rod puppet is not recognized by the Javanese people, most of them are only familiar with Potehi Chinese puppet. This is confirmed by the data that most Chinese emigrants who came to Java is the Hokkien (Fujian) who owned Potehi puppet theater. Some of Potehi playhouse stage are in the form of permanent building of a brick wall that has been decorated with images of deities or knock -down building which is similar to ronda substations that can be assembled. When Potehi stage is used for shows in pagoda, it will be included in the playhouse stage. It is different if the shows take place outside the pagoda, such as in malls, galleries, churches, festivals and so on, then it will be without the playhouse stage. Potehi stage shaped like a castle building with division of imaginary spaces. The upper part is the sky or deities' palace, and the bottom is the human castle. It can also be interpreted as two natures; macrocosm and microcosm. The Sky Palace keep supervising the administration of human castles that have been mandated to regulate human. General grip of Potehi Puppet Theatre in Java includes: material story and a common way of presenting the general grip of the story of Potehi Puppet Theatre in Java that include: materials and way of presenting sequence actions stories that are taken by sehu and the board of pagoda when holding Potehi show in pagoda are as follow: 1 Sehu prepares the figures. 2. Sehu with Lauw $\mathrm{Cu}$ (the board of pagoda) perform Puak Poe rituals. 3. Sehu prepare the staging equipment. 4 . The show is based on the agreed time with pagoda sides. Potehi shows for the Chinese community carry out ritual, social, and educational functions.
\end{abstract}

Keywords: puppet theater; Potehi; Javanese performance

\begin{abstract}
Abstrak
Wayang Potehi di Jawa. Teater Boneka Potehi di Jawa disebut sebagai pertunjukan boneka Cina yang berasal dari Provinsi Fujian dan Guandong. Diduga pertunjukan Potehi datang ke Pulau Jawa pada abad ke-16. Wayang Potehi dikenal sebagai wayang Cina karena bentuknya tidak ditemukan di wilayah Jawa. Wayang kulit di Jawa sama dengan wayang Purwa, wayang bertangkai di Jawa dikenal dengan wayang golek. Teater boneka Potehi dibawa para emigran Hokkian (Fujian) ke Jawa, dan dimainkan pada panggung permanen ataupun panggung yang berpindah. Ketika pertunjukan Potehi dimainkan di Kelenteng, digunakan stage yang permanen berbentuk rumah-rumahan. Hal demikian berbeda dengan pertunjukan yang dimainkan di luar Kelenteng, seperti di mal, galeri seni, gereja, atau festival-festival. Panggung Potehi
\end{abstract}

1 Correspondence: Jurusan Teater, Fakultas Seni Pertunjukan, Institut Seni Indonesia Yogyakarta. Jln. Parangtritis Km 6.5. Sewon Bantul Yogyakarta. E-mail: kuardhani@gmail.com. HP: +62817463468 
merupakan perwujudan simbol dunia, yakni paling atas adalah istana langit yang merupakan tempat para dewa, sementara bagian bawah adalah istana manusia biasa atau tempat masyarakat biasa. Hal tersebut dapat digambarkan sebagai alam makrokosmos dan alam mikrokosmos. Secara keseluruhan, pementasan Potehi di Jawa masih mengikuti patokan, lakon, tatacara Potehi asalnya, yaitu: 1. Sehu atau dalang menyiapkan lakon dan mengajukan judul lakon yang akan dibawakan. 2. Sehu bersama Lauw $\mathrm{Cu}$ (petugas upacara) melakukan ritual Puak Poe. 3. Sehu mendapatkan persetujuan mengenai lakon yang akan dibawakan. 4. Pertunjukan digelar berdasarkan lakon yang telah disetujui dewa. Pertunjukan Potehi bagi komunitas masyarakat Tionghoa membawa serta fungsi sosial, ritual, dan pendidikan.

Kata kunci: teater boneka; Potehi; pertunjukan Jawa

\section{Introduction}

Puppet theatre in Java is usually called wayang. The title of wayang initially meant a shadow show. As time goes by, all kinds of shows in Java using puppet actors, both two dimensional and three dimensional, are called wayang. This paper used the term puppet theater as a translation of puppetry which refers to Potehi. The term puppetry is internationally used in discussions about puppet drama show, including Potehi.

Potehi puppet theater is one of puppet theater (wooden puppet) from Fujian or Hokkian (福建). The word Potehi in Indonesian is derived from Southern Fujian dialect. Kamus Besar Bahasa Indonesia explains Potehi puppet theater as 'Chinese wooden puppet'. It shows that the Potehi puppet theater originated from China.The wooden puppet tradition (puppet theater) originated from China, and it has been known since Siong Theng Dynasty (3000 years ago). The Chinese puppet theater supposedly has had a link with the development of wooden puppet theater which was also found in Hunan (Yunan), Sichuan, Shanxi, Guangdong, and Jiangsu Province. It was also assumed that the tradition of wooden puppet had older age than the development of the puppet theater which has been known since the Song Dynasty (in 960-1278). The puppet theater was peaking at the Ming Dynasty (明) in 1368-1644 until the Qing Dynasty (清) in 1644-1911 (Mastuti cited in Kuardhani, 2011).

The puppet theater in China is known in various forms. The puppet theater forms are wooden, leather, rod, string (marionette), and glove puppet. In addition, there is one puppet which is part of glove puppet namely Potehi puppet theater.

According to Dictionary of Cihai (Chinese Dictionary), Chinese puppet show originated from Han Dynasty (2006SM - 220M) and Song Dynasty (宋) (960M - 1279M). Potehi was popular around South Fujian and Taiwan. Dialogues and songs of Potehi used Southern Fujian dialect accompanied by music; the used of them was found in Quanzhou area accompanied by music Nanqu, while in the Zhangzhou region early was accompanied by Jingdiao music, then it was replaced using Xiangju Opera song until it finally changed with opera song (Yuanzhi, 2005: 319).

Potehi puppet theater in its original country was known as Pouw Tee Hie.Pouw Teemeans sac or sack, Hie means drama. Lombart (1996: 327) mentioned that Potehi is also called Budaixi (布袋戲) which is derived from the wordBudai (sac or sheath). The term Budaixi is a Chinese term that is the national language of China today. Pouw Tee Hie is a Hokkian dialect language [Fukien or Fujian (建)]. According to Gie, a senior puppeteer from Semarang, the word Potehi derives from Poo word which means fabric, Tay word which means sac, and Hie which means puppet (Kuardhani, 2014: 20). Thus, Potehi literally means a puppet glove or a puppet theater of a glove. According toStalberg (1984: 27), among puppet show researchers, the Potehi puppet theater from Fujian or Fukien (建) is known by some English names those 
arecloth bag theatre, theatre the within the palm or tjiangtionghie, and art on the palm. Wu Wei Yun stated that Potehi was a glove theater known as zhangzhongmuou or budaixi; it was also popular with the name of zhihuaxi or finger puppet show [Stalberg, 1984: 27].

Chinese Dictionary says that Potehi is a wooden puppet with a cloth bag, a type of puppet show. Potehi wooden puppet is rather small, the head is connected with a cloth bag, and the outside is worn on stage clothes. The hand of artists were put into the bag to control the motion of the puppet, so it is also called a hand puppet (Yuanzi, 2005: 319).

The art of glove puppet theater or a handbag in Southern China is passed from parent (father) to his child, from generation to generation as preservation and respect for tradition. The Fujian community is proud of their theater arts. Fujian was the center for Potehipuppet theater (gloves), as revealed by Stalberg (1984: 27) below:

Fujian has long been an important center for Chinese puppetry, and particularly hand puppet theatre, one might even call it the heart of classical Chinnese Puppetry. And for this reason, although hand puppetry of other region must be mentioned, our focus will be on the cloth bag theatre of Fujian.

The existence of glove puppet has been believed before $16^{\text {th }}$ century, and it was the creation of a learned scholar in Fujian who wanted to protest openly against treason by Wei Zhongxian eunuch (Stalberg, 1984: 27). There were various versions of Potehi'sorigin. Along with the migration of Hokkian people (Fujian/福建) to Lam-Yang/Nan-Yang (Southern sea), Potehi puppet theater also migrated.

\section{Discussion}

\section{Potehi Puppet Theater Show (布袋戲) in Java}

Potehi puppet theater was allegedly identified as cultural contact between Indonesia and Chinese tribes in the younger period. According to Haryono (2004: 49), the beginning of Potehi puppet theater was known on the island of Java.

In ancient Javanese times of the $\mathrm{X}$ century, puppet shows were well known, and Chinese puppet which was one of the show was even interesting to be mentioned. Those term appeared in younger manuscripts such as Malat and Nawaruci. In Nawaruci was stated Anggambuh, amancangah, alangangkaranmwangawayang China. In Malat was mentioned amancangah, angringgit China. It showed that Chinese puppet reached Java around the XVI or XVII century.

From that opinion, it was suspected that Chinese puppet or Chinese aringgit was a form of Potehi puppet because there was no other type of Chinese puppet theater which has been found in Java. Puppet theater was known for its various types in China, It was similar to Graff's opinion (1998: 190-191) that the similarities between the various types of Javanese puppet and the appearance of Chinese puppet were also known in various forms, but it was difficult to be proved that there was Chinese influence although it was not impossible. Holt (2000: 163) cited the opinion of Serrurier and Sutaarga who mentioned that among the Chinese immigrants, it was known round puppets, but they were hand puppet and strapped Marionette. If Javanese borrowed the idea of round puppets from China, it might be natural for them to change the finger or rope techniques which were known by them for a long time. According to Brandon (2003: 73-74), Potehi puppet form in Java came from China in earlier times, it seen from the following quotation:

It was not clear when Potehi was first shown in Java, but it was probably not before the $20^{\text {th }}$ century, when a large number of Chinese migrated to Java. In Potehi Chinese stories were displayed with Chinese-dressed puppets, but the language spoken by them was Indonesian. It was quite ironic, among many 
forms of Indonesian performing arts, Indonesian as a national language was only used on Potehi which was primary from China. Twenty to twenty-five Potehi puppet troupes operate in Java. They live in Surabaya and Semarang, the two largest cities on the island of Java which have a large Chinese community. These groups mainly hold shows for Buddhist padeitya birthday celebrations. They never hold shows in the public hall and not for private events.

The central tradition in China or the higher Chinese tradition considers puppet theater as a low form of popular entertainment. The puppet theater is associated with pleasure of the less educated people, the illiterate peasants, and the workers. They are the group population of the majority of emigrants who came to Java. One of the reasons why Chinese central tradition was suspicious to puppet theaters related to its function that was as a ritual of evil spirits (Roezendaal in Groenendael 1993: 19). In the past precisely in Java, it was possibly thought that puppet theater Potehi was linked to the ritual of evil spirits, as Groenendael described:

In Java too in the past there may possibly have been a link between Potehiand exorcism as has been suggested by Poensens article. I have no conclusive evidence of more recent exorcistical practices.

In the pre-New Order period, Potehi puppet theater showcan easily be found in various places and events. At the Jakarta Fair, Cap Go Meh Celebration, and Java Annual Fair (Sekatenan night market) in Yogyakarta, a small theater was established exclusively for Potehi puppet show. In 1963 in the city of Semarang, it was easy to find a group of Potehi puppet theaters which showed shows spontaneously in various places, such as markets and bus terminals that many people gathered. The stage was placed on a bullock cart, so the players can carry the stage without having to unpack and install if it moved the stage (Groenendael, 1993: 19).
Since public shows were prohibited during the New Order era, Potehi puppet theaters can only be viewed in the padeitya environment that is in the front yard (Kuardhani, 2018: 32). The audiences are the womb Chinese community that embraces Tri dharma. Most padeityas have a permanent building for the Potehi stage, but there are also padeityas that have a knock-down building which is similar to a guardhouse. House of the stage can be reworking to put Potehi stage if it is needed and will be dismantled when the show is done.

Potehi puppet theater or otherwise known as Potehi puppet, during the Reformation has been started outside the padeitya. Gus Dur issued Indonesia Presidential Decree No. 6 Year 2000 on the Revocation of Presidential Instruction no. 14 Year 1967 on Religion, Belief, and Chinese Customs which established as follow:

First : Revoke the Presidential Instruction Number 14 Year 1967 on religion, belief, and customs of Chinese

Second : With the enactment of this Presidential Decree, all existing implementation provisions due to Presidential Instruction No. 14 Year 1967 concerning Chinese religion, beliefs and customs shall be declared null and void.

Third : It organizes religious activities, beliefs, and customs of China to be implemented without the need for special permits as it goes on.

Fourth : This Presidential Decree is issued on the date of stipulation.

Since the enactment of the Presidential Decree, the Potehi show revived and began to be held outside the padeitya (Kuardhani, 2018: 32).

The Potehi puppet theater belongs to Chinese womb community in Java was originally from Hokkien, it brought to the coastal areas of Java, and it became an interesting form of shows. Potehi puppet theater has adapted to the situation in Java. The Potehi show initially used Hokkian language, then it used the low Malay as Chinese womb ethnic intermediate language, and it currently 
uses Indonesian language. Sehuor puppeteer Potehi do not only come from Chinese ethnic, but it also comes from Javanese who are Moslem, and the number of them is huge.

Potehi puppet theater show originally belonged to the Hokkian Chinese community. As time goes by, other Chinese ethnics in Java felt that they shared the art of the Potehi show, even today the Chinese ethnic outside Java also feel that they have art of Potehi. This is due to the fact that other Chinese ethnic do not have the art of puppet which is brought in overseas and they see Chinese characteristics in the Potehi show, so Potehi performing art has been considered to represent the embodiment of Chinese identity (China).

In its development, the Chinese womb in Java, even outside Java, regarded Potehi as theirs. Potehi puppet has a wider scattering power compared to Gantung puppet in Singkawang. This is due to Potehi puppet theater show in its development using low Malay language which is a lingua franca for Chinese tribes particularly in Java, and generally in Indonesia. Then Potehi puppet theater develops using Indonesian.

The sequences of actions which are undertaken by Sehu and the padeitya administrator when performing the Potehi's (布袋戲) show in the padeitya are as follows:

1. Sehu makes a list of plays on a note or paper.

2. Ritual of Puak Poe. A lauw cu or padeitya administrator and Sehu do Puak Poe ceremony that is burning incense and doing sojathree times to Deity who is

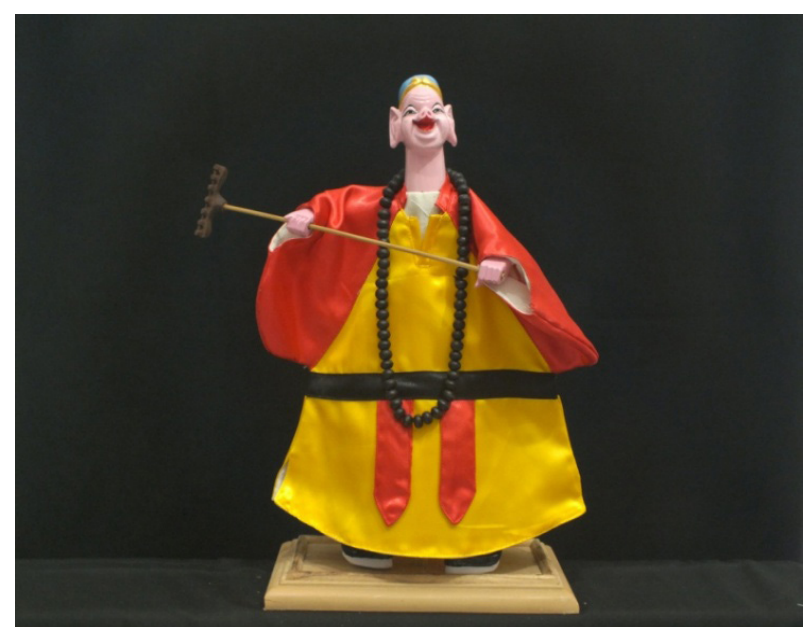

Figure 1. Ti Pat Kai, student of Tong Sam Cong. worshiped at the padeitya. After the prayer, Sehu proposes the titles of the story, then he tosses the seeds of puakpoein front of Deity's statue. If the seeds of puakpoeare open all, it means that the Deity agree with the proposed play.

3. After performing the ritual of play title submitting, Sehu immediately prepares the homes for the Potehi stage, organizes the puppets to be played, and contacts the musician's crew.

4. Prepare the offerings before the play.

Then some offerings are prepared by padeitya's party for the initial show in a number of days that the padeitya wants. Shows for the padeitya can be done in one day, two days, even one week or more, depending on the funds owned by the padeitya and the decision of the board meeting. Mandatory stage is usually done only in one day. When the stage for the padeitya is finished, then the Potehi stage for the next days is joined by the padeitya's congregation who want to perform Potehi stage for the vow ceremony. Therefore, the owner of the event provides offerings. The offerings are started from simple offering which consist of only three kinds of fruit (oranges, apples, and pears) to the complete offerings.

Simple offerings consist of three types of fruit, and the each number of them is three called samseng, for example three oranges, three apples, and three pears, while the offerings which have five amount of each are called ngoseng. Fruit for the purposes of offerings can vary, only durian fruit is

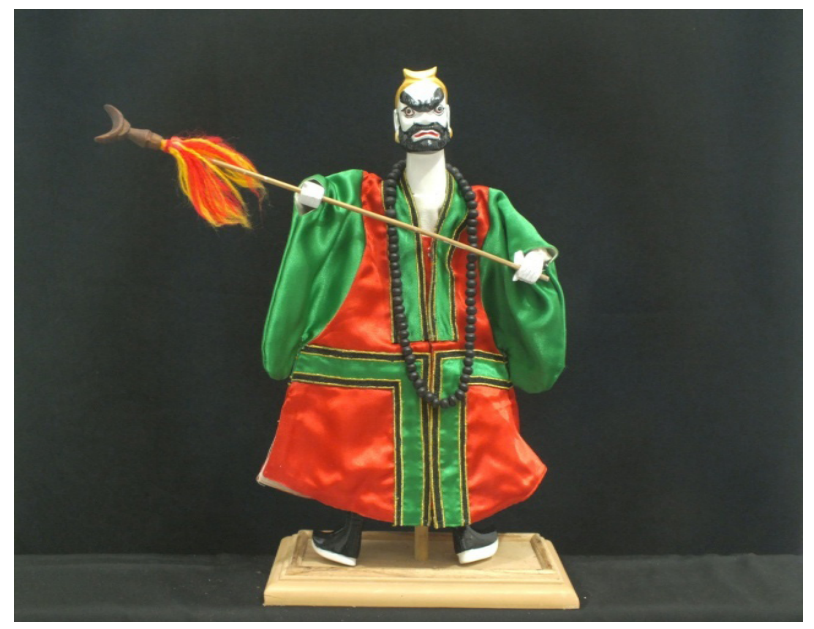

Figure 2. She Go Cing, student of Tong Sam Cong. 
prohibited. Complete offerings are fruits of at least three types (oranges, apples, and pears), roast pork or soy sauce, one chicken cock, a milkfish, various cakes, such as cupcakes, apple cakes, sponge cake, spring rolls, steamed cakes, and others. After the show, offerings can be brought the owner of event to be eaten by his/her family because it is believed that offerings have got blessings from the deity. At the Potehi show shows, sehu begins to play a story that has been approved by deity which is worshiped in pagoda.

The form of the show is everything that is presented in a show, from start to finish, containing certain principles and rules of the show. Each type of show has a distinctive form because it has principles and rules that are different from other types of shows. The following is a form of puppet show Potehi theater in Java.

1. Lauw Tee (opening musical instrument) Starting the show of Potehi, it will be played an opening music like giro in Javanese leather puppet stage. Giro is the term of the sehu to call the booming opening music. In a Javanese show, there is Kebo Giro music for bridal gatherings. The sehu also called Giro for the bride's music. It is intended as a greeting opener and to attract the attention of the audience and the deity if it is staged in pagoda. The opening music is repeated approximately three to four times.

2. Burning gold banknotes (kimcoa)

It is done by sehu, then it is circled around Potehi stage. The show was performed on

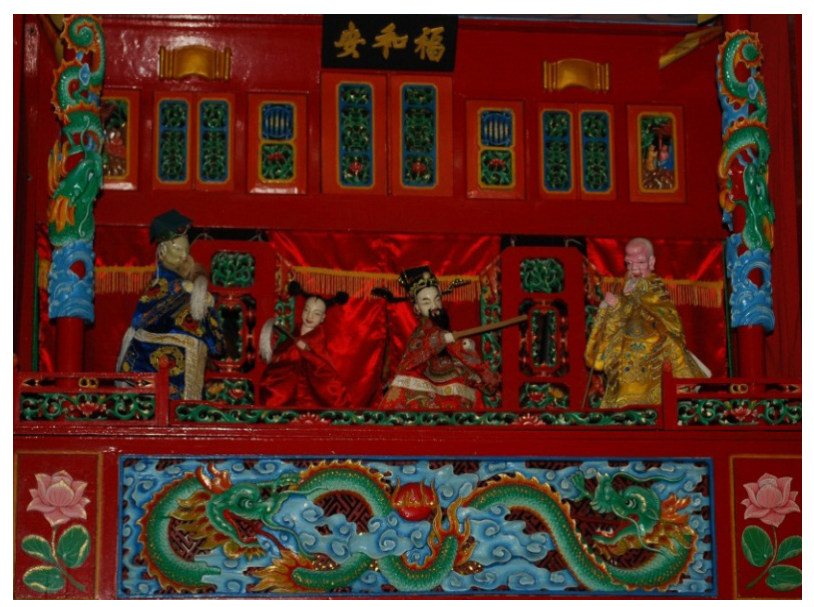

Figure 3. Four Deities descending from the sky. the first day of the show and the last day of the show.

\section{PhayShiu(Ho Sing/TyuLiongTeng)}

In the Potehi show which is performed in pagoda, there is a scene of PhayShiu. It is a scene to chant a prayer witnessed by four deities, and it is performed before staging. The scene is a must-do scene for the Potehi event performed inside the pagoda. When the prayer is prompted, there are four deities descending from the sky, namely Deity of Lam Kek Sian Ong (Deity of Longevity) in yellow, Deity of Jay Sen Yik (Deity of Fortune) in red, Deity of Goat Hee Lo Djin Sian (Deity who holds a matchmaking book of human) in blue or green, and Deity of Siauw Tong Cu (Deity of Descendants) who is tangible as little kid in red.

In non-ritual shows, such as shows at malls, galleries, churches, or on cultural weekend events and others, the scene is not presented, and sehu will open the scene immediately.

\section{Kek Hwan}

After the four deities came down, they give their bless and pray, the scene is continued with the emergence of Fortune Deity (Jay Sen Yik) under the ministries and red shirts. That scene is a compulsory scene.

5. Introduction scene

If the Potehi show is not in pagoda, sehuwill use one of the puppets (not the Deity of Fortune) after the opening instrument to introduce the plays which will be presented and the purpose of show.

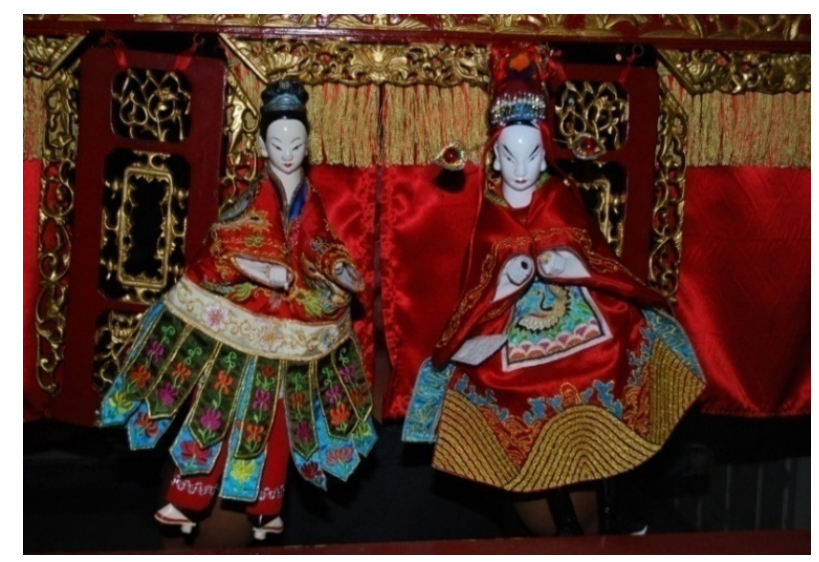

Figure 4. Appears a pair of young brides symbolizing happiness. (Photo was taken by Hirwan Kuardhani) 
6. Main Scene (show of the play)

The styling pattern differs from each play, after the above stages are executed, then sehuis directly entered into the main scene that is playing the story.

7. Closing Scene

\section{a. Pa Shia Sin Bing}

In the closing scenes, sehu will reissue Book Ing character who was originally used to open the story. Then the character will utter the words of farewell to the audience to meet again in the next show. If the puppet show is held in pagoda, it will be announced the plays on tomorrow night which is a continuation of the play that has just been staged. If that day is the last day, while the story has not yet finished, then sehu should mention that on another occasion will be met again.

b. Pa Shia Di

After the Book Ing character did respect three times, there is a pair of young puppet like a new bride which appears on the show. It is a symbol of happiness. A pair of puppet is dressed in red, the man is on the left and the girl is on the right, then they do soja (respect) three times.

\section{The Influence of Indonesia's Historical Social Conditions on Tidal Shows of Potehi Puppet Theater in Java}

The distribution of cultural elements in Potehipuppet theater was due to the spread of emigrants from Hokkian who came to the north coast of Java, and they brought the art of Potehi show. At that time, Javanese society was a community that had culture as well. It meant that they were not in a condition which did not have culture (empty). As a result, there was an acculturation process no matter how slow the process took place. In the process of acculturation, there were creativity and improvisation of culture. Cultural creativity was a creativity which was said to bethe former characterizes creativity by way of its processes, the later by way of its products (Hallam and
Ingold, 2007: 2). It can be interpreted that creativity of culture is actually a process as well as the result of a creativity. According to Ingold and Hallam (2007: 1-7), cultural improvisation contained four things: 1 . generative which means cultivating forms of cultural phenomena throughout a balanced of acculturation life; 2 . relational which means an intense and continuous relationship; 3. temporal which means being temporary and changing at any time; 4. improvisation which means one way of working in reflecting life. The existence of the creativity process and improvisation of culture appears in Potehi show. It can be seen from the use of low Malay (now Indonesian), the insertion of Javanese idioms, and Javanese songs. The process of adjustment to the situation in Java is seen in the form of Potehi stage. According to Hutcheon (2006: 200), the occurrence of adaptation related to economic, cultural, personal, and political factors. Adaptation is not only concerned with the transformation of intrinsic elements, but also extrinsic elements. In adaptation various parts of the elements of art (literature) are reformulated, adapted, and even eliminated. A performing art always reflects the social, cultural, and political background of the community where the show is alive. It can be seen in the adaptation of the Potehi show in Java, for example: many Hokkian speeches were missing or omitted because the later generations of sehu(especially of Javanese) did not master it any more. The political repression of that time also affected the Chinese descendants to reduce the role of the Hokkian language in the show.

The Potehi puppet of Chinese womb is a show part of their religious, religion, belief, and custom ceremonies. Throughout the history of womb Chinese ethnic in Indonesia, especially in Java, they have been involved in a socio-political struggle that has an effect on the continuation of the Potehi stage. Prohibitions in the New Order era for political reasons made the Potehi show undeveloped eventually. Potehi was only played inside the pagoda. As a result, the aesthetic problems of the show declined, due to the limited space. 
Potehi observers and performers can not interact generously to Potehi and Chinese operators from their indigenous country, China. The disconnected relation with China caused the lack of knowledge transfer to the next generation. It happened because sehumust conquer Chinese opera song as one of requirements being a sehu. In addition, Potehi puppet theater showed degeneration in quality.

Political reasons decreased the womb Chinese's interest in Potehi. They did not want to bother dealing with government officials. They chose safety, so they did not involve in activities which were prohibited by the New Order government. Then some Javnese became sehualthough they were Muslim. Consequently, there was an adaptation with local art, such as using ludruk songs or ludrukparikan (short traditional poetry) in the show of Potehi.

The dynamics of performing arts basically shows intercultural dialogue that results in the authenticity of cultural values. Culture is an ever-expanding dialectical process, in the process of tug-of-war and endless bargaining, a process of shaping was built using several elements that were closely related to politics, economics and others (Khayam, 1987: 118120). It was seen in the form of Potehi shows and supporting devices, such as the stage. Some of the stage carvings made in Java have been adapted, even simplified by the sehu or puppeteer according to local conditions. It was triggered because many sehu were not rich, so the selection of stage materials became more economical and simple, like a stage of Gunawansehuthat was not made of teak wood, but from ordinary plywood without carving and simply painted. For them, the main thing was the show and not the stage.

\section{Conclusion}

Potehi puppet theater lovers are not limited to the womb Chinese community, but also local tribes, such as Javanese. At present, the Potehi puppet theaters are mostly Javanese. It shows that Potehi puppet shows are Chinese intercultural bridges located in Java, such as Hokkian, Hakka, and Hokjia Hopek, and also with Javanese, even other tribes outside Java. It is similar to Barongsay art that has penetrated into various tribes in Indonesia and played by various circles. Potehi shows are one of the most popular puppet shows and are the main contributors of the type of puppets in Indonesia. Communities in Java, Bali, Lombok, and parts of Kalimantan have the art of leather puppet and wooden puppets. However, none of the areas in Indonesia have hand puppet. Therefore, the presence of Potehi puppet that has been harmoniously adapted to other archipelago art forms increases the variety of Indonesian puppet that is in the form of hand puppet.

\section{References}

De Graff, HJ. 1998. Cina Muslim di Jawa Abad XV, Antara Historis dan Mitos. Yogyakarta: Tiara Wacana.

Groenendael, Victoria Clara Van. 1993. "Pote-hi: The Chinese Glove Puppet Theatre in East Java". Bernard Arps (Ed.), Performance in Java and Bali Studies of Narrative, Theatre, Music, and Dance. London: School of Oriental and African Studies University of London.

Halam, Elizabeth \& Hallam \& Tim Ingold, (Ed). 2007. Creativity and Cultural Improvisation. New York: Berg Oxford.

Haryono, Timbul. 2004. Seni Pertunjukan pada Masa Jawa Kuna. Yogyakarta: Pustaka Raja.

Hutcheon, Linda. 2000. A Theory of Adaptation. New York: Routledge.

Kayam, Umar. 1987. "Keselarasan dan Kebersamaan: Suatu Penjelajahan Awal" dalam Prisma, Volume XVI, No. 3, Maret 1987.

Kuardhani, Hirwan. 2018. Teater Boneka Potehi dan Budaya Tionghoa Peranakan di Indonesia. Yogyakarta: Diandra.

Kuardhani, Hirwan. 2018. Teater Boneka Potehi Persebarannya di Beberapa Negara. Yogyakarta: Diandra.

Lombart, Denys. 1996. Nusa Jawa Silang Budaya. Jilid 2. Jakarta: Pustaka Utama. Stalberg, Roberta Helmer. 1984. Cina's Puppet. 
San Fransisco: Cina's Book. Yuanzi, Kong. 2005. Silang Budaya Tiongkok
Indonesia. Jakarta: Bhuana Ilmu PopulerKelompok Gramedia. 